\title{
Living the Experience of Old Age Forgetfulness with People for Whom We Care
}

\author{
Bill Rollans
}

University of Alberta

A good memory does not guarantee wisdom, humour, kindness or love. ${ }^{1}$

Iris

Until recently, I'd been confident that I had a good memory. That doesn't mean that I hadn't had my share of sudden blanks, where a name that I knew as well as my own darted from the tip of my tongue to Lord knows where. It's hard to believe, but it happened to me with my husband's name only weeks after we were married. We ran into an old friend of mine-you knew Lydia Johnson - and for some reason I was completely unnerved. Lydia's name stood out like it was on a billboard, but my husband's name had vanished without a trace. I used my best delaying tactics, but they didn't help, so I ended up saying, crossly I'm afraid, to Fred: "Well, tell Lydia who you are." Even though I'd experienced many similar memory lapses over the years, I'd never seen them as ominous. They were just embarrassing incidents to laugh over later with family or friends. Forgetting, in those days, just seemed to be a natural consequence of having too many things on my mind, or of not being very interested. But forgetting is far more familiar, and far less amusing, as we grow older. That doesn't mean that we can't laugh about it among ourselves. Let me show you a folksy poem that Jean sent me inside a belated-chuckle--birthday card. It's called "From One Senior Citizen to Another." Here's a few lines:

Sometimes I can't remember

As I stand at the foot of the stairs,

If I'm going up for something

Or I've just come down from there.

The ending's the best part.

P.S. Here I stand beside the mailbox

With my face so very red

Instead of mailing you my letter

I have opened it instead. 
On the side she wrote: "See what's ahead." What a prospect!

I had hoped to look at the experience of forgetting as experienced by Iris, a fictitious composite of all the forgetful old people I have met in my own life, in the recollections of others I interviewed and in the pages of texts and literature. ${ }^{2} B u t ~ I$ soon discovered that the difficulities that the aged with memory deficits experience in processing the events of the present seem to hamper their ability to reflect on the experiences of the present, and that my questions that were directed at uncovering these experiences seemed to elicit hurt and confusion, but few lucid insights. This left me uncomfortable to pursue these frailties when I could offer no remedies to compensate for the discomfort that I evoked. Fortunately I have been honored by voluntary or gently encouraged glimpses into the uncertain realms of other relatives' and friends' memories, and I will share these scenes with you as I attempt to uncover, with the help of the fictional Iris, what it is like for us to experience the forgetfulness of old age in others and in ourselves. Iris will speak in regular type, and I will use italics.

\section{What's in a Name Forgotten?}

I wish that I could be as accepting and as practical as an old acquaintance was about his "forgettery," as he called it. He was a retired minister, and the way he told his favourite sudden blank experience was priceless. It had to do with the story of Ruth, you know"Whither thou goest, I will go," and "Thy God shall be my God." She was to be the core of his sermon, but when he faced his congregation, without notes, he could remember every name in the "good book" but Ruth's. So he went through the entire sermon without ever mentioning her by name. He extolled the virtues of that "Great Moabite," the compassion of "Naomi's daughter-in-law," the faithfulness of "The Wife of Boaz," and the devotion of "Obed's Mother."

Forgetting names like that isn't forgetting people. I wouldn't even say it was forgetting. It's just a temporarily empty space. Maybe names go visiting in our minds. And I can guess where Fred's had been visiting although I'd rather not. That's why The Reverendhis name escapes me-made no mistakes regarding the realities of Ruth, and I certainly knew all there was to know about Fred, so it makes me wonder. Are names really as important as some people make out? Does it really matter whether or not we take our husbands' names, or if we change them to fit some mathematical configuration like Stella did when she became Allama, or to proclaim a religious conversion like Cassius Clay/Mohammed Ali? I think that who we are is quite independent of the label that we, or someone else, hangs on us. Allama's tongue is every bit as sharp as Stella's. Don't you think that names are too easily forgotten, at any age, to be very central to our Beings? 
But it wasn't just names that Iris forgot. She forgot important interactions that she had with people, including the people themselves if they were strangers. "Seldom seen, soon forgotten" gains pertinence as we age. One of my favorite Iris stories came from when she was introduced to several of my son's friends. Derek was wearing a T-shirt that he had purchased on a recent athletic trip to Berkeley. It has CAL emblazoned on the front. After the introductions, Iris said: "I'm getting forgetful, but I sure won't forget your name, Cal."

\section{Memoranda Memory}

Such lapses can occur at any age, I know, but it had never before happened to my old friend-I almost had his name-in the pulpit until he was "getting on," and it marked the beginning of his notes to himself-his "paper memory."

Lewis Carroll had a special understanding of the many problems associated with aging, and his stories are a rich source of quotations for writers in gerontology. In Through the Looking Glass, the White King has just been dusted off in mid-air by an invisible Alice:

"The horror of that moment," the king went on, "I shall never, never, forget!"

"You will, though," the Queen said, "if you don't make a memorandum of it."

Memoranda slowly became the most valuable assets in his memory bank. And he had sound advice about keeping it active. A note by the phone that says "Helen-Friday" in my handwriting, or gives only a phone number or an address, can really unsettle me. He said that notes should all be dated and include enough information to be understood by a stranger because that is how his old mind-and mine-often views information from the recent past.

The psychologist Donald O. Hebb (1978) had been reading a scientific article that was directly related to his work, and as he read he thought "I must make a note of this." Then he turned the page and found a pencilled note in his own handwriting. "I was used to forgetting things that didn't interest me," he said, "but even then I always knew when I was reading something a second time" (p.19).

When you can't remember why you wrote the note in the first place you are afraid that it may have more import than appears on the surface. There's a note sitting in front of me right now that says "date cookies." Does it just mean that my cookie jar is empty, or has Jessie phoned to say that she is coming over, and I know how she loves those cookies? You like them too, I remember that. Even 
though you aren't much for sweets, you never say no to my date cookies. Then again the note could mean that someone from the church phoned about a bake sale, and I promised to send over some cookies. Or it could be a note from ages ago that has fallen out of the phone book. When you're not sure what's coming next, you learn to handle surprises. If I thought that I could learn the lines, I'd try for a stage career. But when I write the notes, their purposes seem so clear. They're meant only to be a nudge for a mind that seems so acute at the moment. How can it dull so quickly? What happens in my head to chase it away? Or what doesn't happen in my head to hold it in place? Whatever is or isn't taking place, I know that I should be doing something about it. But I'm not motivated by much these days. My zest for living has lost its "zing." The things I cared so much about in the past don't seem to matter anymore. You know how I've hoarded, guarded, and displayed my best china ever since I started collecting it right after the war. Well, right now it doesn't mean-snap-to me. I can't even be bothered to decide who should have it when I'm gone. It really doesn't matter to me what happens to anything once I'm dead. Could it be nature's way of weaning me from the breast of the belongings that I have fed on, but that I must soon leave behind? Sometimes I feel like a child again, unconcerned about the uncertainties ahead.

\section{Forgotten Childhoods}

I read somewhere that we are once an adult but twice a child. We don't remember the events of our early childhood and often don't remember the events of our old age. There must be a connection. Are there things that happen during our beginnings and endings that are too painful to be remembered?

In my dreams I'm often a child, but I'm never old. Could my crumbling body be the illusion and the dream be the reality? I'm almost convinced that that's the situation, especially when I look in a full length mirror when I'm naked. That's not the me whose mind can romp through the memories of a vigorous past. My physical being is only limiting a mental being that is ready and waiting to rebound to peak vitality. I do have faith. I do believe that there is much more to being than living. But lately, my Being is often weary of living in this old body with its childish mind. Is that how it is at the end of all of life's stages? Does the next stage entice us before it arrives? I know that childhood doesn't last forever, be it first or second. I'm almost ready for the next stage, and I don't think that it will be second adolescence. I still remember that I feared death when I was younger, but I can no longer resurrect the feeling. Death has taken on a friendlier guise. 
I was the executor of Iris' estate and was very concerned that her wishes should be carried out after her death. It was a frustration to me to find that she really had so few. She was, however, willing to humour me occasionally and make some suggestions regarding the disposition of her personal effects. But she really didn't want to be bothered. She seemed ready to move on.

But there was no giving up for Reverend Gleeson. I knew that I'd get his name! He got quite excited telling about his weekly paper chase. He'd gather up all notes from pockets, wallet, desk and bulletin boards. Those that were no longer relevant would be destroyed or revised to usefulness. Otherwise they'd just confuse, and add to the clutter that seems to plague many old people-especially me! He wrote "paper chase" on every Friday on his calendar. I know it's a good idea, but I don't do anything about it. I have notes all over the place that I can't figure out, but I don't seem to be able to throw them away. Throwing anything away is a problem to me. Am I clinging to the past, or am I just not coping well with the present? It could be a lot of both!

With Iris' permission, early in her decline, I toiled through piles of paper to find a letter that was urgently needed by her lawyer. Although the letter had arrived no more than three weeks earlier, I found it near the bottom of a pile of letters, papers, memoranda, recipes, greeting cards, clippings, bits of paper-clean on one side-for use as more notes, and carefully folded wrapping paper from gifts of yore. There were also substantial cheques and unpaid bills. They had been handled often because the accumulation of three years since her husband's death had been thoroughly shuffled together. There was no semblance of organization into categories or sequences. Apparently each journey through the pile was, for her, a circle tour that led neither to consolidations in memory nor appropriate actions. Letters did not prompt replies and cheques did not create or earn interest.

\section{The Living Dead}

"Out of sight-out of mind" seems to describe the way my memory works, or doesn't work, these days. It doesn't seem to apply to the dead, though. The line that marks the living from the dead when we are young can appear much less distinct when we are old. Take Fred for instance, he's been dead for-I don't know how long-and yet I know that I often speak as if he is still living. "We always shop at Safeway." "We never sleep in." "We watch sports on T.V." I know that he's gone, but I guess I don't want to admit that he isn't coming back. Could using "we" keep me from feeling as alone as I know I am? Do we mask our memories for the comfort necessary to survive? 
When Jessie came to call, I asked her where Archie was, completely forgetting that he had died. I may have gone to his funeral though I can't be sure. It wasn't an easy moment for either of us, but she is a dear. I probably offered her tea and then forgot to serve it. She wouldn't think of embarrassing me by mentioning it.

Would she have remembered more if we hadn't been so sensitive and kind? Could we have jarred her into remembering not to forget so much? Perhaps friends should be more sensitive to our needs than to our sensitivities. Could Iris have handled the truth and benefitted from it? Certainly she was aware of changes, but she didn't share them as concerns. They usually came out as somewhat humorous anecdotes.

And then there was the time I found this hat in Woolco that was just the right colour to go with Fred's new tweed jacket. It wasn't until I was in the line-up for the cashier that it struck me: Fred's dead and his new tweed coat went to Goodwill the day after his funeral. I felt more foolish than sad, so I can't really have forgotten that he was gone. But still, it is funny-peculiar, that is. How can I keep the hurt of his passing out of my mind?

The Christmas after Fred died, I received a card from "Fred and Iris," and the Christmas after Iris died, a card addressed to her was forwarded to me. It had been sent by Jessie who had served refreshments at Iris' funeral. It seems cold to throw "dead" mail away and unfeeling to return it to the sender when you know the situation. So you open it, feeling guilty, but mostly sad-sad for the living more than for the dead.

Fred's place was forever secure in Iris' memory.

I'm always thinking: I'll have to tell Fred about this and that as soon as I get home. But he isn't there when I get home, and I know it before I start looking for my key.

\section{Where Did I Put lt?}

And what a problem keys are. Not just keys, of course, because I always seem to be looking for my glasses, my purse or something, but mostly it's my house key that seems to stray. I know it is because I worry about it so much. I'm forever putting it someplace where it will be so obvious that I can't miss it on the way out-but I do.

Donald Hebb (1978) was able to assess his own deficits and to suggest a solution. "I have long believed that the best way to remember to take something with me is to put it on the doorstep, so I see it when I leave: now (that I am old) this works better if the object is big enough to trip over" (p.19). 
Maybe I should tape my key to my nose. It isn't much of a bother right now though because when I came home some time ago (Quite some time ago!), I couldn't find my key in my purse so I picked up a brick that I used as a door stop and knocked out one of the panes of glass in the front door. I've covered it over with a brown mailing envelope, which is good enough to keep most of the cold air out, and it sure makes it easy for me to get in when I forget my key. I'm not as worried about thieves as I am about being locked out. Besides, when I'm in the house, I keep my storm door locked, and when I'm out of the house, it doesn't really matter. Except for my wedding ring, which I never take off, I don't own anything that I couldn't live without.

How can things that once seemed worth a lifetime of working, scrimping, and saving for seem to lose all of their value? Is it because we have forgotten what made them so important? Or is it because we finally see them for what they really are?

I also wonder why old people will do just about anything to keep other people from finding out about their forgetfulness? I remember reading about an old man who locked his house keys, along with his car key, in his car on a very cold day. Rather than go for help, he fished around with a piece of wire until he froze to death. And I've done things that could have turned out just as badly; all because of some foolish pride.

I remember one summer day-before I broke the window in the door-when I arrived home without my key. I scouted around the house and found that the bathroom window was open a crack. You know our house has quite a high basement, so that window was way out of my reach. Well, I spied the picnic table and dragged it over, set a wooden box from under the porch on top of it, and proceeded to climb-headfirst_through the window. I gave myself some nasty bruises, but I didn't break anything.

Dylan Thomas must have had such a woman in mind when he wrote:

Do not go gentle into that good night,

Old age should burn and rave at close of day;

Rage, rage against the dying of the light.

Why do we put such dogged reliance on our failing faculties? Are we so isolated in the prisons of our aged minds that we are no longer free to locate alternatives that include other persons? Are we allowing our pride to block us, even dangerously, from baring the realities of our incompetence? Or do we, like the old professor in On Golden Pond, "not want crowds of people watching (us) grow old." 
I know that I'm getting independent to a fault, and I'm afraid that my fall may come before my pride "goeth."

\section{Don't Remember, But I Didn't Forget}

I can still make an effort in practical situations, but nowadays, some things just don't seem worth doing or even thinking about much. And if you don't think much about them, you probably don't learn them. And if you haven't learned them, how could you be accused of forgetting them? Down at the Seniors' Centre a while back, a fellow was asking questions as part of some memory research. He asked old Emery who the prime minister of Canada was. Emery's answer was: "At 89 years of age, what the hell difference does it make." It was probably marked wrong, but I don't think that it was wrong because Emery really doesn't have any interest in knowing who the prime minister is. Do you think he needs to know that? Who is the prime minister anyway?

Iris didn't know and didn't care. And she didn't care that I knew that she didn't know and didn't care. It marked the beginning of increased openness that remained to the end.

I'm not so sure that forgetting is the opposite of remembering. There's a difference between the things that I don't remember and the things that I can't remember. There are things that I used to know that I can't remember, and I know that I've forgotten them, but there aren't very many important things that fit that category. But there are lots of things these days that I don't remember, and knowing that I could remember them if I paid more attention to them makes me angry at myself. But it doesn't mean that I write myself off as hopeless. The things that I don't remember aren't really forgotten; I just didn't bother to learn them. Maybe I'm just not giving things the attention they need to commit them to memory. What I'm trying to say is that what I don't do today doesn't mean that I can't do it tomorrow. Do you think that I'm fooling myself? Am I beyond repair? Should I no longer hope for my tomorrows?

Had Iris reached the stage that Narihiri writes about?-

I have always known

That at last I would

Take this road, but yesterday

I did not know that it would be today.

I seem to be making a fuss and getting tangled up over the word "forgetting," but I looked up its roots in your big dictionary while you were getting the coffee, and I didn't like what I found. It comes from an old Teutonic word, getan, which meant "to hold" or "to grasp." 
That means that forgetting is mighty close to "losing your grip." And I'm not crazy about the mental-breakdown sound of that. Maybe I should have used "thrilled about" instead of "crazy about," but then, crazy does seems to fit some of the things that I do.

\section{Confabulation}

I'm probably the world's best-meaning worst—confabulator. Do you know that word?

In memory circles, to "confabulate" means to "chat with your self" to come up with a logical explanation for something that you can see has happened, but that you have no clear recollection of happening. Simon Hornstein (1971) provides a more scholarly explanation:

Confabulation consists of the completion (or filling in) of defective recollections by the introduction or construction of a plausible but inappropriate item to complete the gap. Some confabulations are thought to represent memory fragments, and others, incorrect associations leading to an account of an event that never happened. .. Confabulation has been regarded as ... an expression of denial of illness, and as mnemonic "completion" or compensation for memory loss of which the patient has some awareness. (p. 40)

When we are young, it's usually clever deduction, but when we are old, there's a good chance that it's just faking; and in Iris' case, it was usually more transparent than clever.

Do you see through my acts and laugh about them with Marie? I wouldn't blame you because they can be hilarious.

Did I ever tell you about the false teeth? No? (Of course she had.) Well, it was while we were still in the old house, probably in the early thirties. I was cultivating around our front hedge when I dug up some false teeth - a partial plate. It had obviously been there a long time, but I cleaned it up till it looked like new. Then, as practical jokers are wont to do, I set my mind to thinking how to get the most fun out of it. I decided that putting it in Fred's good suit offered the most interesting possibilities. You know he never wore a suit to work, and he wasn't one to be in church every Sunday, so it was weeks before he put on that suit. And he didn't discover the denture until he was searching for a handkerchief in the middle of the anthem. The startled look he gave me as he covertly displayed the denture was almost more than I could handle, but I managed-barely. I sat back for days listening, fit to burst, as he constructed explanation after explanation for it being in his pocket. Finally, his confabulation was complete. He decided that it had happened when he was riding between old friends-you remember Paul and Millie from Calgary? They were all in the front seat of Paul's car when Millie's 
denture began to bother her. She slipped it out and, since she wasn't carrying a purse, dropped it into Fred's pocket, absent-mindedly assuming it was Paul's. I agreed that that seemed possible, but when he decided to call her, even though I assured him that she must have obtained a replacement long since, I had to come clean. He showed a little anger at first but soon switched to admiration for one of my best "scams."

Years later we discovered, and that's a story in itself, that it had belonged to an inebriated young man who had seen my sister, Flo, home from a dance. After bidding her goodnight, he proceeded to lose his drinks and his denture in the shrubbery. The next day he neither remembered being ill nor walking Flo home. Oh, we've had some laughs over that whole affair.

I wonder how Iris could remember every detail of Fred's confabulation and seem unaware of her own? When I asked her who did her shopping, she said that she did it at Safeway, and that she took the car for her big order on Thursdays after she had had lunch at the Centre.

Iris hadn't driven the car since Fred died, and the battery had long since lost its charge. For a year or more she went to Safeway by bus and then started walking to a small convenience store two blocks away. When her niece discovered that she was buying only bread and ice cream, she began bringing in a nutritious selection each week. Iris packed them into her fridge and cupboards herself, and she paid for them with money that was hidden all over the house.

I had access to her funds and brought her more money than she needed each month. I saw that she had a good variety of bills and change so that she didn't have to panic when someone had to be paid in cash. There was money under the doily on the hall table so the paper boy didn't have to wait for his collection: there was money between the blotter sheets on Fred's old desk, and under the fruit bowl on the dining room table; under the telephone, and in full view on the mantle. But sometimes, when she needed a larger bill, she went into her bedroom and came out with one that always showed the effects of having been tightly rolled.

The retrieval of this money never failed to lead her to recall her sister Martha's declining years. She had said then that if she ever got as forgetful as as her sister, she would like to be "put away." She had no wish to become an object of amusement and pity. Iris was now at much the same stage of senile regression. And though Iris remembered everything about Martha's last years, she did not seem to remember her own fears. She was determined to remain in her own home even after she had become reclusive, depending on 
relatives for shopping and business affairs. She wouldn't even go to the doctor although she should have gone. It was, I'm convinced, because she was afraid that she wouldn't be brought back. And if she had gone on her own, I think that she knew that she may not have found the doctor's office or her way home.

She still enjoyed talking about Martha's problems, though, and could even relate them to her own situation.

I'm just like Martha was. I'm even hiding my money in the toes of old shoes. You know, it does seem like a safe place. But I'm not wearing two dresses at a time like she did-chuckle-so I've a way to go. Still, I know that I have to start working at my memory.

\section{Confusion}

I can't even recall exactly what I did this morning. Is that when Jessie called, or was that after lunch? Maybe it wasn't even today. It's not important, but it bothers me not to know. I rack my brains, but the morning is hidden.

Sometimes when I can't remember doing something and yet can't recall not doing it, I get flustered. Right now, I'm wondering. Have I done or said anything amiss? Have I mumbled to myself or talked louder than I should? You see, at this moment everything looks clear to me, but what happened just before? That's what worries me. It's like waking from a dream.

Iris' experiences are surprisingly similar to those described by Igor Stravinsky (1968):

I am pained, too, by sudden memory blanks; this is like waking at night in a foreign hotel and not knowing where you are. And my memory taunts me; while I may be unable to find the right address in it for an event of a month ago, and while yesterday is vague and last week might have evaporated, a great deal that was etched there three quarters of a century ago seems to lie on the tip of my tongue. (p.6)

I just don't remember things like I used to. But that's not surprising when you consider that I'm over $60 \ldots$ Am I really over 80 ? Well, of course, you're right. I suppose I repeat myself too? Yes. Well, my life's not very interesting, so I guess if I'm going to say anything that I know anything about, I'll be repeating myself. Why do you put up with such an old bore?

I haven't put up with the Irises in my life. I have sometimes resented the demands that our relationships have imposed on my time, but I have never doubted their inestimable value. They are our links with a past that was ours before we were born and with a future that we have experienced through their lives. 
Robert Browning wrote:

Grow old along with me.

The best is yet to be.

Could Iris have made the best of what was yet to be without her "forgettery?"

"Happy 85th birthday Iris!," I said, lovingly.

"Same to you Bill!" she replied, with equal affection.

How fortunate we are that feelings and familiar faces are somehow still lingering, long after the "facts" have been forgotten.

\section{Notes}

1. From my notes from a conference in Edmonton on technological change in 1983. Neither my notes nor my memory clearly identify the speaker.

2. I have borrowed several sentences from Margaret Laurence's moving novel, Stone Angel. I invite you to read this novel to meet Iris' contemporary, Hagar.

\section{References}

Hebb, D. O. (1978, November). Watching myself grow old. Psychology Today, 15-23.

Hornstein, S. (1971). Amnestic, agnosic, apractic, and aphasic features in dementing illness. In C. E. Wells (Ed.), Dementia. Philadelphia: F. A. Davis.

Stravinsky, I. (1969, April 24). The New York Review of Books. 12(8), 6. 